\title{
Spanish Heart Transplant Registry. 31th Official Report of the Heart Failure Association of the Spanish Society of Cardiology
}

\author{
Registro Español de Trasplante Cardiaco. XXXI Informe Oficial de la Asociación de \\ Insuficiencia Cardiaca de la Sociedad Española de Cardiología
}

Francisco González-Vilchez ${ }^{\mathrm{a}}$, Luis Almenar-Bonet ${ }^{\mathrm{b}}$, María G. Crespo-Leiro ${ }^{\mathrm{c}, \mathrm{d}}$, Manuel Gómez-Bueno ${ }^{\mathrm{e}}$, José González-Costello ${ }^{\mathrm{f}}$, Félix Pérez-Villa ${ }^{\mathrm{g}}$, Juan Delgado-Jiménez ${ }^{\mathrm{d}, \mathrm{h}}$, José María Arizón del Prado ${ }^{i}$, José Manuel Sobrino-Márquez ${ }^{j}$, Iago Sousa Casasnovas ${ }^{\mathrm{k}}$, on behalf of the Spanish Heart Transplant Teams

\footnotetext{
Servicio de Cardiología, Hospital Universitario Marqués de Valdecilla, Santander, Cantabria, Spain Servicio de Cardiología, Hospital Universitario y Politécnico La Fe, Valencia, Spain

Servicio de Cardiología, Complexo Hospitalario Universitario A Coruña (CHUAC), Universidade da Coruña (UDC), Instituto de Investigación Biomédica A Coruña (INIBIC), A Coruña, Spain

d Centro de Investigación Biomédica en Red de Enfermedades Cardiovasculares (CIBERCV), Spain

e Departamento de Cardiología, Hospital Universitario Clínica Puerta de Hierro, Majadahonda, Madrid, Spain

$f \quad$ Servei de Cardiologia, Hospital Universitari de Bellvitge, L'Hospitalet de Llobregat, Barcelona, Spain

$g \quad$ Servei de Cardiologia, Hospital Clínic Universitari, Barcelona, Spain

h Servicio de Cardiología, Fundación Investigación Hospital Universitario 12 de Octubre, Facultad de Medicina, Universidad Complutense de Madrid, Madrid, Spain

Servicio de Cardiología, Hospital Universitario Reina Sofía, Córdoba, Spain

j Servicio de Cardiología, Hospital Universitario Virgen del Rocío, Sevilla, Spain

k Servicio de Cardiología, Hospital Universitario Gregorio Marañón, Madrid, Spain
}

\begin{abstract}
Introduction and objectives

The present report describes the clinical characteristics and outcomes of heart transplants in Spain and updates the data to 2019 .
\end{abstract}

Methods

We describe the clinical characteristics and outcomes of heart transplants performed in Spain in 2019, as well as trends in this procedure from 2010 to 2018. 
In 2019, 300 transplants were performed (8794 since 1984; 2745 between 2010 and 2019). Compared with previous years, the most notable findings were the decreasing rate of urgent transplants (38\%), and the consolidation of the type of circulatory support prior to transplant, with an almost complete disappearance of counterpulsation balloon $(0.7 \%)$, stabilization in the use of extracorporeal membrane oxygenation $(9.6 \%)$, and an increase in the use of ventricular assist devices (29.0\%). Survival from 2016 to 2018 was similar to that from 2013 to $2015(\mathrm{P}=.34)$. Survival in both these periods was better than that from 2010 to 2012 ( $\mathrm{P}=.002$ and $\mathrm{P}=.01$, respectively).

\section{Conclusions}

Heart transplant activity has remained stable during the last few years, as have outcomes (in terms of survival). There has been a trend to a lower rate of urgent transplants and to a higher use of ventricular assist devices prior to transplant.

Keywords:

Cardiac transplant; Registry; Survival

\section{Resumen}

\section{Introducción y objetivos}

Se presentan las características clínicas y los resultados de los trasplantes cardiacos realizados en España con la actualización correspondiente a 2019.

\section{Métodos}

Se describen las características clínicas y los resultados de los trasplantes cardiacos realizados en 2019, así como las tendencias de estos en el periodo 2010-2018

\section{Resultados}

En 2019 se realizaron 300 trasplantes (8.794 desde 1984; 2.745 entre 2010 y 2019). Respecto a años previos, los cambios más llamativos son el descenso hasta el $38 \%$ de los trasplantes realizados en código urgente, y la consolidación en el cambio de asistencia circulatoria pretrasplante, con la práctica desaparición del balón de contrapulsación $(0,7 \%)$, la estabilización del uso del oxigenador extracorpóreo de membrana $(9,6 \%)$ y el aumento de los dispositivos de asistencia ventricular (29\%). La supervivencia en el trienio 2016-2018 es similar a la del trienio 2013-2015 ( $\mathrm{p}=0,34)$, y ambas mejores que la del trienio 2010-2012 ( $\mathrm{p}=0,002$ y $\mathrm{p}=0,01$ respectivamente).

\section{Conclusiones}

Se mantienen estables tanto la actividad del trasplante cardiaco en España como los resultados en supervivencia en los últimos 2 trienios. Hay una tendencia a realizar menos trasplantes urgentes, la mayoría con dispositivos de asistencia ventricular.

Palabras clave:

Trasplante cardiaco; Registro; Supervivencia 


\section{Introduction}

In 2019, the heart transplant field celebrated its 35th anniversary in Spain. The Spanish Heart Transplant Registry was formed at the end of 1989 and published its first activity report in Revista Española de Cardiología in 1991.1 Produced under the principles of accountability and transparency, these documents have annually reported the activity and outcomes of all heart transplants carried out in Spain since the first such procedure was performed in 1984. Over time, the Spanish Heart Transplant Registry has become an essential tool for reporting the latest aspects of clinical practice in our country, as well as a clinical research platform. 2

The present report provides an update on the activity and outcomes of the Spanish Heart Transplant Registry until December 31, 2019, with a special focus on the last 10 years.

\section{Methods}

\section{Patients and procedures}

A summary has already been published of the main methods used in the Spanish Heart Transplant Registry.3 In 2019, an adult heart transplant program was started in Dr Negrin University Hospital of Gran Canaria, bringing the total number of active centers to 19. There have been no changes from previous years in the structure of the activity of the distinct hospitals (eg, pediatric transplant, multiorgan transplant)4,5 (table 1). From 1984 to 2019, 8794 transplants were performed (figure 1); the Spanish Heart Transplant Registry has complete follow-up information on 8782 of these transplants, which form the basis of the current analysis. The types of transplants performed in 2019 and in the entire series are summarized in table 2. This report provides the relevant data for 2019 and compares them with those of the last 10 years (2010-2019). The changes over time for the period under study were analyzed in 3-year periods (2010-2012, 2013-2015, and 2016-2018), except for the percentage of urgent transplants, the types of pretransplant circulatory support, and donor age, which were analyzed by year.

Table 1. Hospitals participating in the Spanish Heart Transplant Registry from 1984-2019 (in order of first transplant performed)

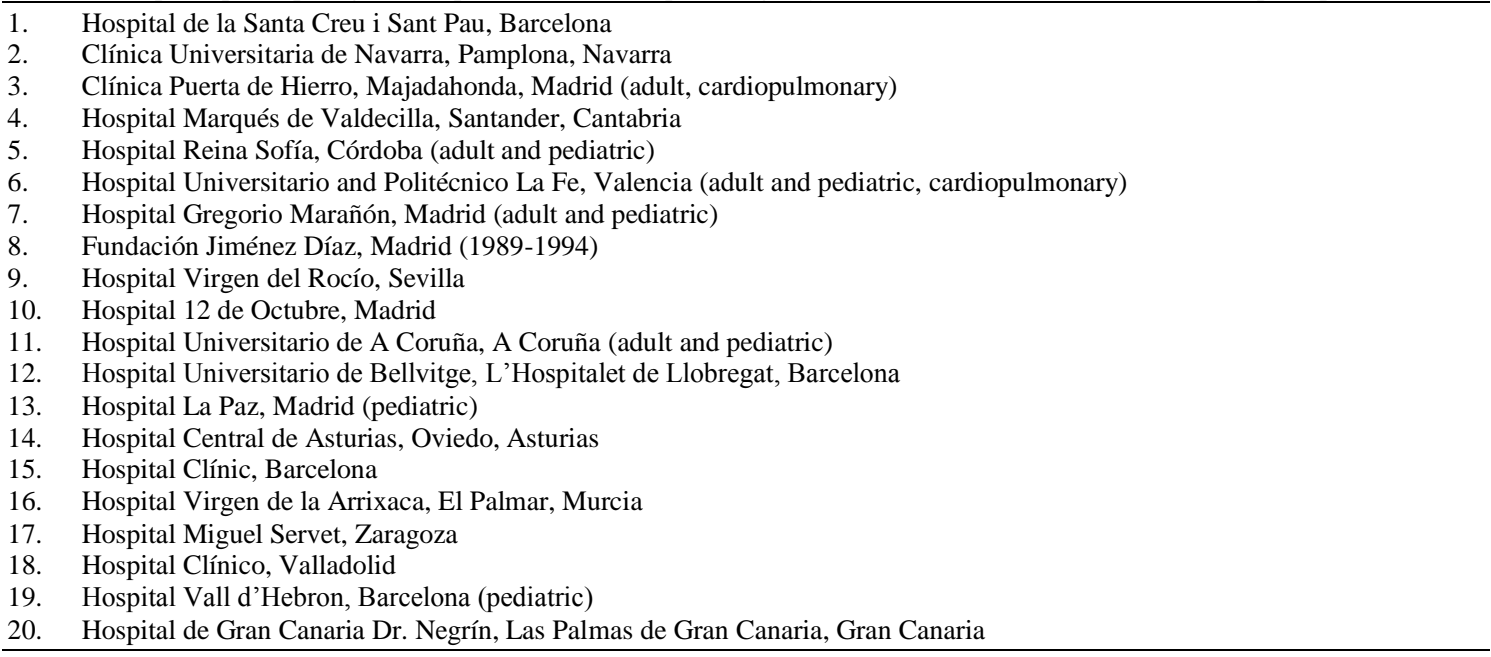




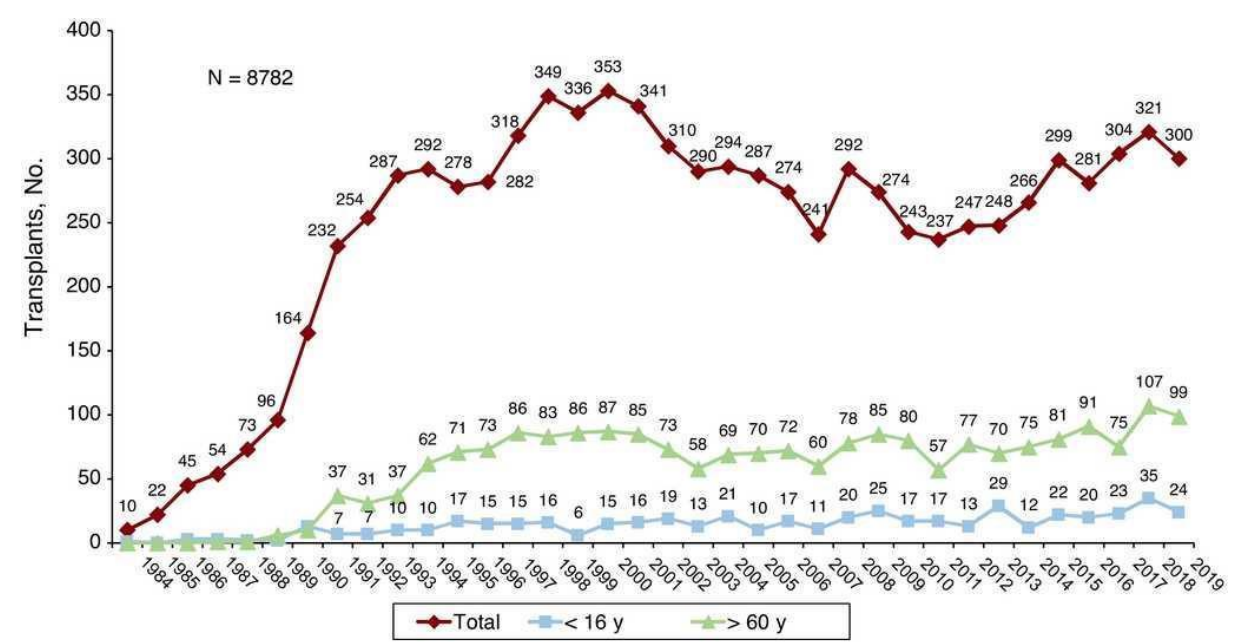

Figure 1. Annual number of transplants (1984-2019), total and by age group.

Table 2. Procedure type in the Spanish Heart Transplant Registry (1984-2019)

\begin{tabular}{lll}
\hline Procedure & 2019 & $1984-2019$ \\
\hline De novo heart transplant & 289 & 8409 \\
Heart retransplant alone & 5 & 198 \\
Combined heart retransplant & 1 & $7^{*}$ \\
Combined de novo heart transplant & 5 & 168 \\
Heart-lung & 1 & 83 \\
Heart-kidney & 2 & 73 \\
Heart-liver & 2 & 12 \\
Total & 300 & 8782 \\
\hline
\end{tabular}

"All kidney transplants.

\section{Statistical analysis}

Continuous variables are expressed as mean \pm standard deviation, whereas categorical variables are expressed as percentages. Differences among time periods were analyzed using a nonparametric test for time series data (Kendall $\tau$ ) for categorical variables and ANOVA (analysis of variance) with polynomial fit for continuous variables. Survival curves were calculated using the Kaplan-Meier test and were compared using a log-rank test. $\mathrm{P}<.05$ was considered statistically significant.

\section{Results}

\section{Recipient characteristics}

Recipient characteristics are summarized in table 3. A total of 300 transplants were performed in 2019. Compared with 2018 , the decrease in the number of procedures was mainly due to fewer pediatric patients (younger than 16 years old). The mean recipient age was $49.5 \pm 17.8$ years, with no significant changes in the last 10 years. Overall, $72.3 \%$ were men, confirming the trend in the last decade for an increase, albeit nonsignificant, in transplants in women. The percentages of multiorgan transplants and retransplants were stable, at about $2 \%$ overall. In the last 10 years, the only significant trends were the improvement in renal function at transplant and the increase in pretransplant cardiac surgery (both $\mathrm{P}=$ .04). The latter variable was correlated with increased use of ventricular assist devices in 2019, with a tendency for a slight decrease in the use of extracorporeal membrane oxygenation (figure 2). There was a major decrease in urgent procedures in 2019 (38.0\%) vs the tendency of previous years $(46.8 \%$ in 2016 2018) (figure 3). 
Table 3. Recipient characteristics in the Spanish Heart Transplant Registry (2010-2019)

\begin{tabular}{|c|c|c|c|c|c|}
\hline & $\begin{array}{l}2010-2012 \\
(\mathrm{n}=726)\end{array}$ & $\begin{array}{l}2013-2015 \\
(n=813)\end{array}$ & $\begin{array}{l}2016-2018 \\
(\mathrm{n}=906)\end{array}$ & $\begin{array}{l}\mathrm{P} \\
\text { for trend }\end{array}$ & $\begin{array}{l}2019 \\
(n=300)\end{array}$ \\
\hline Age, $y$ & $50.3 \pm 16.3$ & $48.8 \pm 17.1$ & $49.1 \pm 17.7$ & .18 & $49.5 \pm 17.8$ \\
\hline$<16 \mathrm{y}$ & 6.5 & 7.7 & 8.6 & .11 & 8.0 \\
\hline$>60 y$ & 29.3 & 27.8 & 30.1 & .66 & 33.0 \\
\hline Male sex & 76.3 & 74.4 & 72.4 & .07 & 72.3 \\
\hline BMI & $25.0 \pm 4.7$ & $24.5 \pm 4.5$ & $24.7 \pm 4.9$ & .09 & $24.8 \pm 4.9$ \\
\hline Underlying heart disease & & & & .35 & \\
\hline Nonischemic dilated & 37.3 & 35.9 & 37.0 & & 38.0 \\
\hline Ischemic & 35.8 & 36.7 & 32.6 & & 31.7 \\
\hline Other & 26.9 & 27.4 & 30.5 & & 30.3 \\
\hline PVR, WU & $2.2 \pm 1.3$ & $2.2 \pm 1.3$ & $2.2 \pm 1.3$ & .72 & $2.1 \pm 1.3$ \\
\hline Glomerular filtration rate, $\mathrm{mL} / \mathrm{min} / 1.73 \mathrm{~m}^{2}$ & $76.7 \pm 34.5$ & $79.6 \pm 36.5$ & $80.5 \pm 37.7$ & .04 & $79.1 \pm 38.4$ \\
\hline Bilirubin $>2 \mathrm{mg} / \mathrm{dL}$ & 15.5 & 16.2 & 16.9 & .48 & 12.8 \\
\hline Insulin-dependent diabetes & 17.9 & 22.1 & 21.1 & .16 & 19.0 \\
\hline Moderate-to-severe COPD & 7.7 & 11.8 & 10.5 & .10 & 10.2 \\
\hline Previous infection & 13.7 & 14.5 & 16.0 & .18 & 12.5 \\
\hline Previous cardiac surgery & 29.1 & 34.6 & 34.2 & .04 & 38.7 \\
\hline Type of transplant & & & & .75 & \\
\hline Single & 96.0 & 96.3 & 96.7 & & 96.3 \\
\hline Heart retransplant & 2.1 & 1.8 & 1.5 & & 2.0 \\
\hline Combined & 2.1 & 1.6 & 2.1 & & 2.0 \\
\hline Heart-lung & 1.2 & 0.9 & 1.0 & & 1.0 \\
\hline Heart-kidney & 0.7 & 0.7 & 0.7 & & - \\
\hline Heart-liver & 0.1 & - & 0.3 & & 0.3 \\
\hline Pretransplant mechanical ventilation & 14.9 & 15.2 & 14.5 & .79 & 18.1 \\
\hline Urgent transplant & 36.2 & 45.9 & 46.8 & $<.001$ & 38.0 \\
\hline Pretransplant circulatory support & & & & $<.001$ & \\
\hline No support & 69.7 & 62.1 & 58.3 & & 60.8 \\
\hline Balloon pump & 14.7 & 13.5 & 4.1 & & 0.7 \\
\hline ECMO & 6.4 & 11.2 & 10.5 & & 9.6 \\
\hline Ventricular assist device & 9.3 & 10.5 & 27.1 & & 29.0 \\
\hline
\end{tabular}

BMI, body mass index; COPD, chronic obstructive pulmonary disease; ECMO, extracorporeal membrane oxygenation; PVR, pulmonary vascular resistance.

Values are expressed as percentage or mean \pm standard deviation.

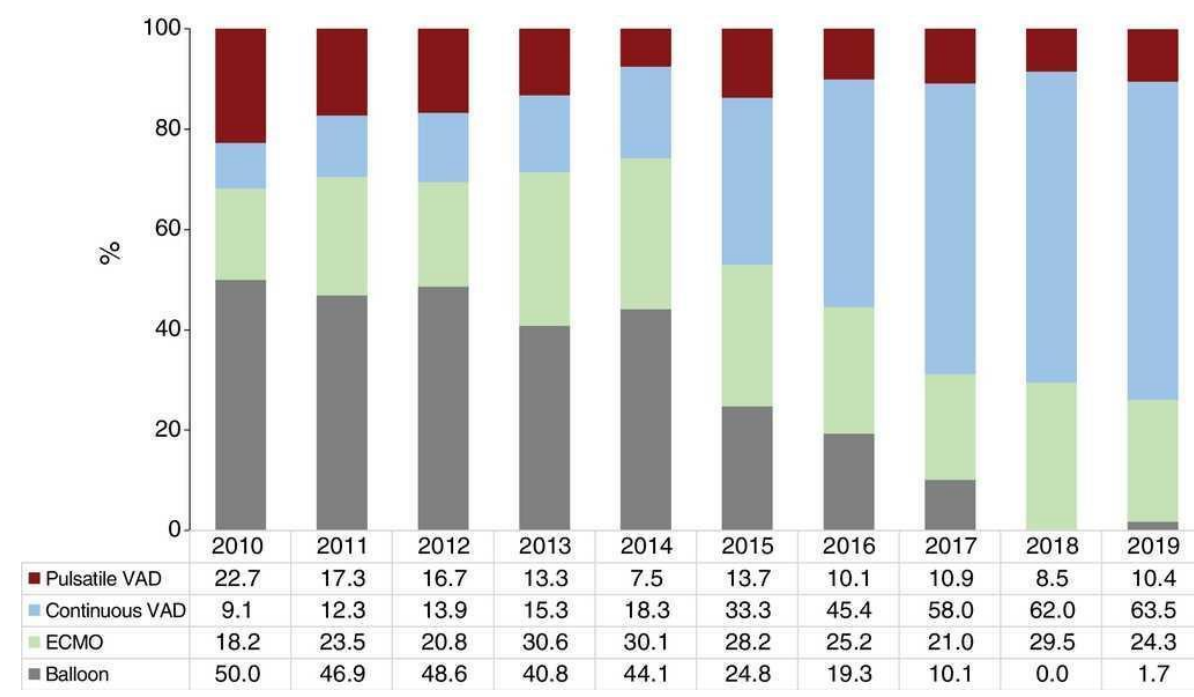

Figure 2. Type of pretransplant circulatory support by year (2010-2019). ECMO, extracorporeal membrane oxygenation; VAD, ventricular assist device. 


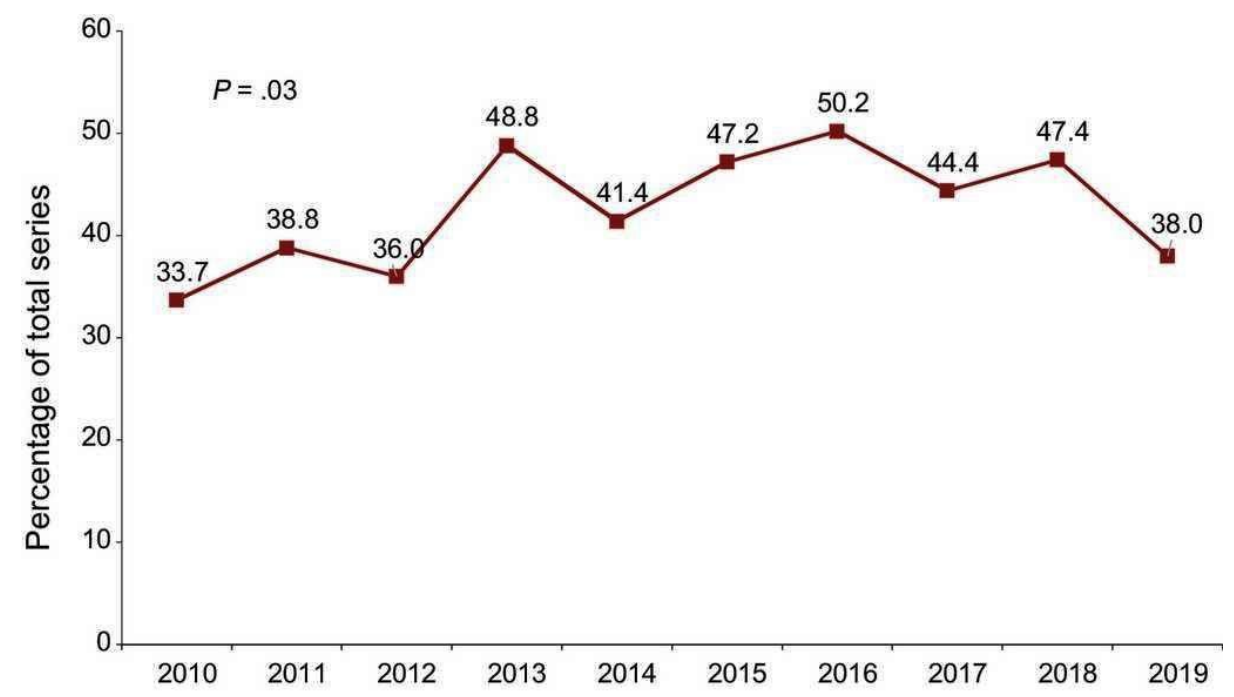

Figure 3.Percentage of urgent transplants performed annually for the full series (2010-2019).

\section{Donor characteristics and ischemia time}

Donor characteristics are summarized in table 4. Donor age was stable vs the previous 3-year period, although the tendency for an increase in the last 10 years was highly significant. In $2019,55 \%$ of donors were older than 45 years of age (figure 4). There was a slight decrease in the number of donors who died of stroke, with a corresponding increase in those who died of other causes. There was another small but consistent increase in the number of donors with pretransplant cardiac arrest (18\% in 2019), although there was also a decrease in donors with mild dysfunction on pretransplant echocardiography. The cold ischemia time fell again, a tendency seen in the last 10 years, with an average time in 2019 of a little more than 3 hours In addition, almost 3 of every 4 transplants were performed with a bicaval technique, a trend that now appears established.

Table 4. Donor characteristics and procedure times in the Spanish Heart Transplant Registry (2010-2019)

\begin{tabular}{|c|c|c|c|c|c|}
\hline & $2010-2012(n=726)$ & $2013-2015(n=813)$ & $2016-2018(n=906)$ & $\mathrm{P}$ for trend & $2019(n=300)$ \\
\hline Age, y & $39.2 \pm 14.0$ & $42.4 \pm 14.6$ & $43.4 \pm 15.5$ & $<.001$ & $43.1 \pm 16.0$ \\
\hline Age $>45 y$ & 39.4 & 50.1 & 57.3 & $<.001$ & 55.3 \\
\hline Male sex & 65.6 & 57.3 & 61.0 & .11 & 61.2 \\
\hline Female donor-male recipient & 21.4 & 26.1 & 22.1 & .94 & 22.1 \\
\hline Weight, kg & $73.8 \pm 17.0$ & $73.3 \pm 18.8$ & $74.2 \pm 19.3$ & .60 & $75.6 \pm 20.2$ \\
\hline Recipient:donor weight & $0.94 \pm 0.19$ & $0.93 \pm 0.20$ & $0.94 \pm 0.21$ & .43 & $0.92 \pm 0.20$ \\
\hline Recipient:donor weight $>1.2$ & 7.1 & 7.1 & 7.6 & .66 & 4.7 \\
\hline Recipient:donor weight $<0.8$ & 19.0 & 21.6 & 23.8 & .02 & 25.7 \\
\hline Cause of death & & & & $<.001$ & \\
\hline Trauma & 31.4 & 24.1 & 21.2 & & 21.7 \\
\hline Stroke & 46.6 & 49.6 & 54.1 & & 50.7 \\
\hline Other & 22.0 & 26.3 & 24.7 & & 27.6 \\
\hline Pretransplant cardiac arrest ${ }^{\mathrm{a}}$ & 9.8 & 17.2 & 17.4 & $<.001$ & 18.0 \\
\hline Pretransplant echocardiography ${ }^{\mathrm{b}}$ & & & & .15 & \\
\hline Not performed & 3.0 & 1.3 & 1.8 & & 0.9 \\
\hline Normal & 94.8 & 95.5 & 95.4 & & 97.4 \\
\hline Mild generalized dysfunction & 2.3 & 3.2 & 2.8 & & 1.7 \\
\hline Ischemia time, $\min$ & $210.9 \pm 61.8$ & $202.6 \pm 67.4$ & $197.3 \pm 73.0$ & $<.001$ & $195.0 \pm 72.7$ \\
\hline$\leq 120$ & 9.9 & 12.5 & 17.9 & .001 & 18.3 \\
\hline $120-180$ & 19.0 & 22.5 & 19.8 & & 22.0 \\
\hline $180-240$ & 41.8 & 38.3 & 34.7 & & 34.0 \\
\hline$>240$ & 29.2 & 26.7 & 27.7 & & 25.7 \\
\hline Bicaval surgical technique & 66.3 & 67.5 & 72.3 & .008 & 73.6 \\
\hline
\end{tabular}

Values are expressed as percentage or mean \pm standard deviation.

${ }^{\text {a }}$ Of 2331 transplants.

${ }^{\mathrm{b}}$ Of 2254 transplants. 


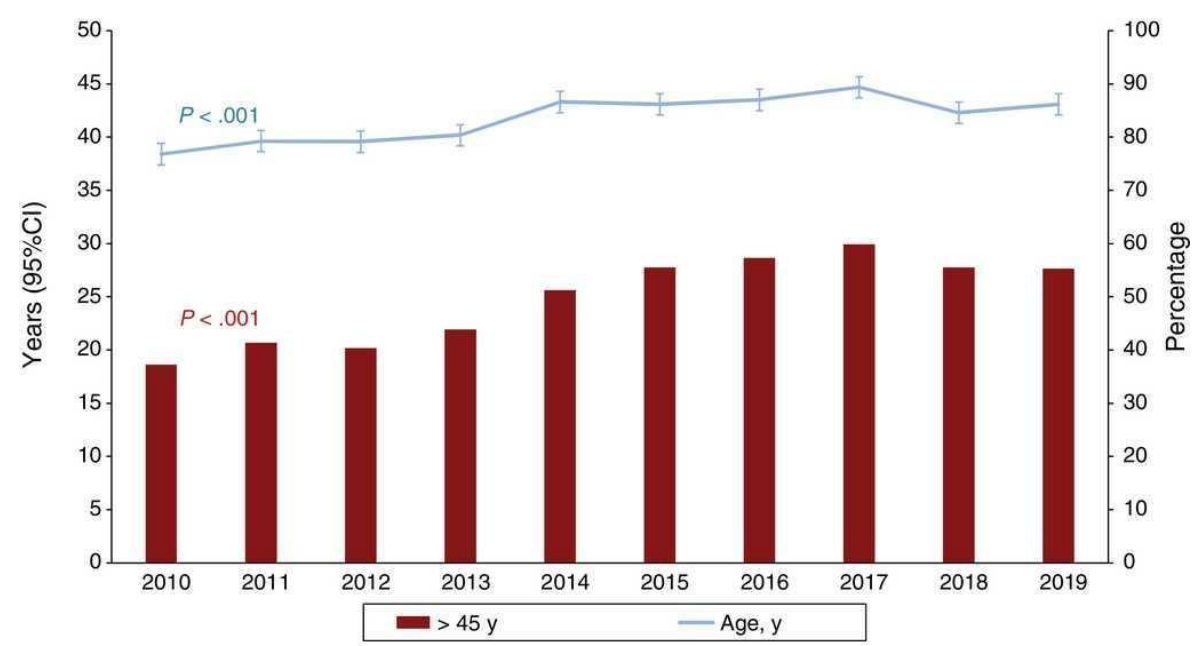

Figure 4. Annual changes in donor age and percentages of donors older than 45 years (2010-2019). 95\%CI, 95\% confidence interval.

\section{Immunosuppression}

Induction immunosuppression strategies are summarized in table 5. In 2019, the tendencies seen in the last decade were confirmed, with the almost exclusive use of triple therapy comprising tacrolimus, mycophenolate, and steroids. Likewise, more than $80 \%$ of patients received antibody-based induction therapy, mainly basiliximab.

Table 5. Induction immunosuppression in the Spanish Heart Transplant Registry (2010-2019)

\begin{tabular}{|c|c|c|c|c|c|}
\hline & $2010-2012(n=726)$ & $2013-2015(n=813)$ & $2016-2018(n=906)$ & $\mathrm{P}$ for trend & $2019(n=300)$ \\
\hline \multicolumn{6}{|l|}{ Calcineurin inhibitors, $\%$} \\
\hline Cyclosporin & 30.3 & 12.0 & 5.3 & $<.001$ & 5.0 \\
\hline Tacrolimus & 69.7 & 88.0 & 94.7 & $<.001$ & 95.0 \\
\hline \multicolumn{6}{|l|}{ Antiproliferative agents, $\%$} \\
\hline Mycophenolate/mycophenolic acid & 99.6 & 99.1 & 99.5 & .95 & 100 \\
\hline Azathioprine & 0.4 & 0.9 & 0.5 & .95 & 0 \\
\hline \multicolumn{6}{|l|}{$m$ TOR inhibitors, $\%$} \\
\hline Sirolimus & 0.4 & 0.3 & 0.6 & .60 & 0 \\
\hline Everolimus & 2.3 & 2.1 & 1.3 & .15 & 1.2 \\
\hline Steroids, \% & 95.9 & 97.1 & 97.0 & .25 & 97.8 \\
\hline Induction, $\%$ & & & & .08 & \\
\hline Not used & 13.9 & 13.8 & 17.1 & & 19.2 \\
\hline ALG/ATG & 3.6 & 2.7 & 4.3 & & 2.7 \\
\hline Anti-CD25 & 82.1 & 83.1 & 77.4 & & 77.8 \\
\hline Other & 0.4 & 0.4 & 1.2 & & 0.3 \\
\hline
\end{tabular}

ALG, antilymphocyte globulin; anti-CD25, basiliximab or daclizumab; ATG, antithymocyte globulin.

\section{Survival}

Survival was significantly better from 2010 to 2019 than from 1984 to 2009 (figure 5). This improvement was evident in both early survival (first posttransplant year) and mid-term survival (until the fifth posttransplant year). The final 3-year period (2016-2018) showed a significant improvement in survival vs the 2010 to 2012 period, although survival was similar to that of the immediately preceding period (2013-2015) (figure 6). 


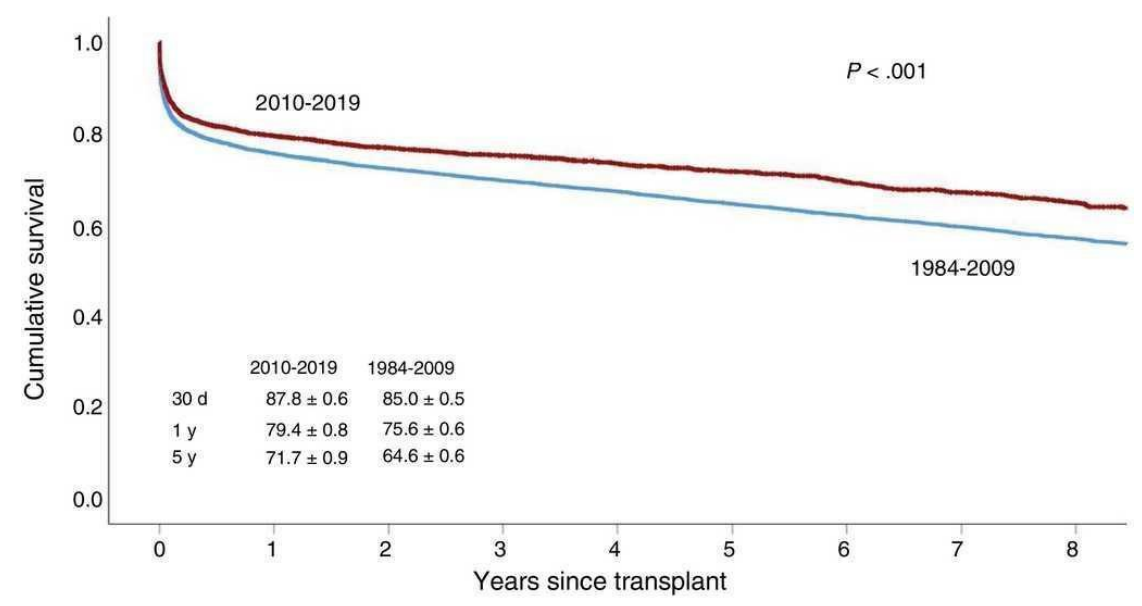

Figure 5. Comparison of survival curves between the periods 2010 to 2019 and 1984 to 2009.

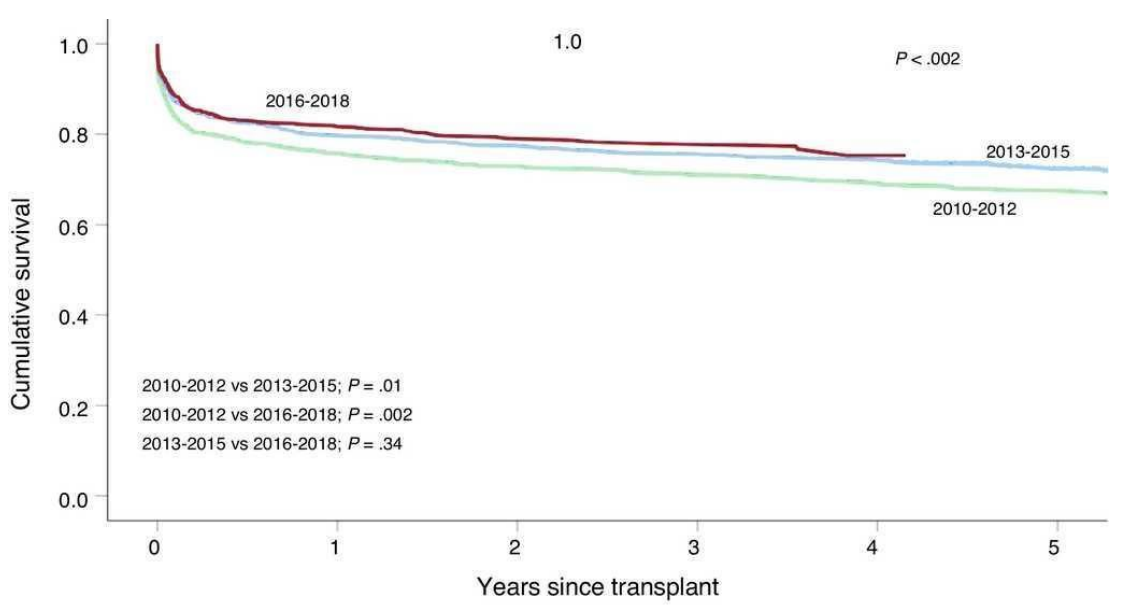

Figure 6.Comparison of survival curves from 2010 to 2018 by 3-year period.

Factors related to survival from 2010 to 2019 (table 6) were maintained at similar levels to those of previous reports. 3 The most notable result was that recipient age was associated with survival, unlike donor age. Recipient age $>60$ years exerted a highly significantly effect on survival vs age $<16$ years $(\mathrm{P}$ $=.004)$. As in previous analyses, combined transplant and urgent transplant, due to the effect of pretransplant extracorporeal membrane oxygenation, continued to be associated with worse survival vs heart transplant alone and elective transplant, respectively.

\section{Causes of death}

Infection, primary graft failure, and graft vascular disease/cardiac arrest were the most frequent causes of death in the first 5 posttransplant years during the last decade (figure 7). As expected, death from primary graft failure was concentrated in the first posttransplant month, causing a third of deaths. The leading cause of death in the period between the first month and first posttransplant year was infection (40.8\% of cases), but was graft vascular disease/cardiac arrest between the first and fifth years $(28.9 \%)$. These proportions mirror those observed in previous reports, as do the high incidence of death due to acute rejection observed between the first and fifth posttransplant years (18.6\%) and that due to cancer in the same period. 
Mortality in the first year due to primary graft failure and acute rejection stabilized in 2019. In contrast, 2019 showed a reduction of almost one-half in patients who died of infection in this early period (figure 8).

Table 6. Univariable survival analysis by baseline recipient, donor, and procedure characteristics (2010-2019)

\begin{tabular}{|c|c|c|}
\hline & Hazard ratio $(95 \% \mathrm{CI})$ & $\mathrm{P}$ \\
\hline \multicolumn{3}{|l|}{ Recipient age } \\
\hline$<16 \mathrm{y}$ & 1 & \\
\hline $16-60 y$ & $1.2(0.9-1.6)$ & .21 \\
\hline$>60 \mathrm{y}$ & $1.6(1.1-2.2)$ & .004 \\
\hline \multicolumn{3}{|l|}{ Type of transplant } \\
\hline Single & 1 & \\
\hline Combined & $1.6(1.0-2.4)$ & .049 \\
\hline Retransplant & $1.4(0.9-2.2)$ & .19 \\
\hline \multicolumn{3}{|l|}{ Donor age } \\
\hline$\leq 45 \mathrm{y}$ & 1 & \\
\hline$>45 \mathrm{y}$ & $1.0(0.9-1.2)$ & .75 \\
\hline \multicolumn{3}{|l|}{ Urgency code } \\
\hline Elective & 1 & \\
\hline Urgent & $1.2(1.0-1.4)$ & .009 \\
\hline \multicolumn{3}{|l|}{ Type of support } \\
\hline No support & 1 & \\
\hline Balloon pump & $1.0(0.8-1.2)$ & .80 \\
\hline ECMO & $1.7(1.4-2.1)$ & $<.001$ \\
\hline Ventricular assist device & $1.1(0.9-1.4)$ & .19 \\
\hline
\end{tabular}

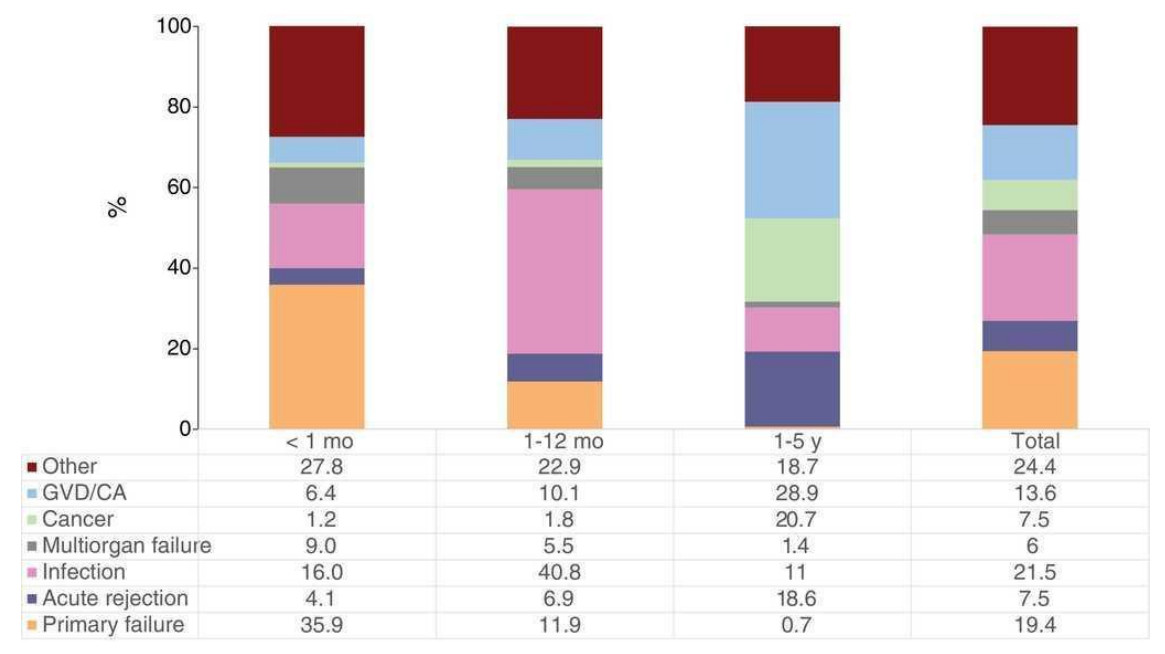

Figure 7. Main causes of death by time since transplant in the 2010 to 2019 period. GVD/CA, graft vascular disease/cardiac arrest. 


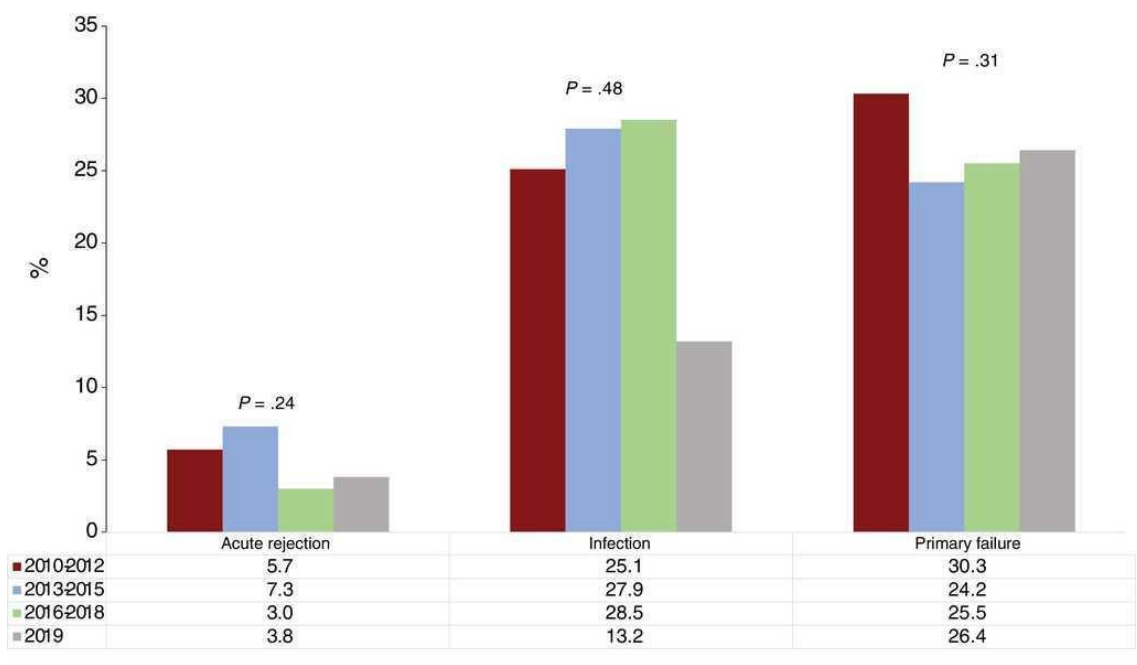

Figure 8. Changes over time in the main causes of death in the first posttransplant year from 2010 to 2018 by 3 -year period.

\section{Discussion}

The main findings of the present updated analysis of the Spanish Heart Transplant Registry are as follows: a) confirmation of the trends detected in the last decade regarding the main recipient, donor, surgical procedure, and outcome characteristics; b) the apparent stabilization of these trends in 2019 vs the 2016 to 2018 period; and c) the striking change in the rate of urgent transplant and, related to this, the differences in the use of the various circulatory support devices.

The trends in the last decade that have tended to stabilize in the most recent period include the higher proportion of women receiving transplants, the improved pretransplant renal function, the higher age of donors, the use of donors with a larger body size than recipients, the use of donors who have had a cardiac arrest, the greater use of the bicaval technique, and the shorter ischemia time. Nonetheless, the most striking novelty is related to the type of pretransplant circulatory support, with an increase in ventricular assist devices, a stabilization in the use of extracorporeal membrane oxygenation (the only such procedure available in some hospitals), and the almost complete disappearance of balloon pump therapy.6 Consequently, there was an increase in sternotomy history (standard for ventricular assist device implantation) and decrease in urgent transplants. These changes are related to modifications in the inclusion criteria for the urgent waiting list introduced halfway through 2017 by the Spanish National Transplant Organization after an analysis of data from the Spanish Heart Transplant Registry.7 In the new criteria, the need for balloon pump support is no longer considered a situation necessitating urgent transplant and the window has been limited for the inclusion of patients receiving extracorporeal membrane oxygenation.

As has been the norm in previous reports, survival continues to improve. Thus, in the last decade, the 5-year cumulative survival was $71.7 \%$, similar to that reported by the registry of the International Society for Heart and Lung Transplantation.8 However, analysis of the survival curves of the most recent 3-year periods seems to show that outcomes have been stable since 2013. The differences in the first posttransplant year were stable among periods. Although the result was not significant, our findings indicate that the improvement since 2013 might be related to reduced death from primary graft failure and stabilization of that from infection.

\section{Conclusions}

Spanish heart transplant activity in 2019 showed a stabilization of trends observed in the previous decade in terms of recipient, donor, surgical procedure, and outcome characteristics. Survival has been stable since 2013 . 


\section{Conflicts of interest}

None declared.

Appendix.collaboratorsinthespanishhearttransplantregistry,1984-2019

Hospital
Clínica Universitaria Puerta de Hierro, Majadahonda, Madrital Universitario y Politécnico La Fe, Valencia
Hospital Universitario de A Coruña, A Coruña
Hospital Universitario Reina Sofía, Córdoba
Hospital Universitario Marqués de Valdecilla, Santander,
Cantabria

Hospital Gregorio Marañón (adults), Madrid

Hospital Universitario 12 de Octubre, Madrid

Hospital de la Santa Creu i Sant Pau, Barcelona

Hospital Universitario Virgen del Rocío, Sevilla Hospital Universitario de Bellvitge,

L'Hospitalet de Llobregat, Barcelona

Clínica Universitaria de Navarra, Pamplona, Navarra Hospital Clínic Universitari, Barcelona Hospital Universitario Central de Asturias, Oviedo, Asturias

Hospital Universitario Gregorio Marañón (pediatric), Madrid

Hospital Universitario Virgen de la Arrixaca, El Palmar, Murcia

Hospital Universitario Miguel Servet, Zaragoza

Hospital Clínico Universitario, Valladolid

Hospital Universitario La Paz, Madrid

Hospital Universitario Vall d'Hebron, Barcelona

Hospital Universitario de Gran Canaria Dr. Negrín, Las Palmas de Gran Canaria, Gran Canaria
Collaborators

Javier Segovia-Cubero, Francisco

Hernández-Pérez

Soledad Martínez Penades, Mónica

Cebrián Pinar, Raquel López Vilella, Ignacio Sánchez-Lázaro, Luis

Martínez-Dolz

María J. Paniagua-Martín, Eduardo

Barge-Caballero, Gonzalo Barge-

Caballero, David Couto-Mallón

Amador López Granados, Carmen

Segura Saintgerons, Víctor Menjíbar

Pareja, Francisco Carrasco Ávalos

Manuel Cobo, Miguel Llano-

Cardenal, José A. Vázquez de Prada,

Francisco Nistal Herrera

Zorba Blázquez, María Jesús Valero, Carlos Ortiz, Eduardo Zataraín,

Adolfo Villa, Paula Navas, Manuel

Martínez-Sellés

M. Dolores García Cosío, Laura

Morán Fernández, Pedro Caravaca

Vicens Brossa Loidi, Eulàlia Roig

Minguell, Sonia Mirabet Pérez, Laura

López López, Isabel Zegrí

Diego Rangel Sousa

Nicolas Manito Lorite, Carles Díez Lopez, Josep Roca Elias, Elena

García Romero

Gregorio Rábago Juan-Aracil

María Ángeles Castel, Marta Farrero

José Luis Lambert Rodríguez, Beatriz

Díaz Molina, María José Bernardo

Rodríguez, Cristina Fidalgo Muñiz

Manuela Camino López, Juan Miguel

Gil Jaurena, Nuria Gil Villanueva

Iris Garrido-Bravo, Domingo A.

Pascual Figal, Francisco J. Pastor Perez

Teresa Blasco-Peiró, Ana Portoles

Ocampo, Marisa Sanz Julve

Luis de la Fuente Galán, Javier Tobar

Ruiz, Amada Recio Platero

Luis García-Guereta Silva, Álvaro

González Rocafort, Carlos Labradero

de Lera, Luz Polo López

Ferrán Gran Ipiña, Dimpna C. Albert

Brotons, Raúl Abella Antón

Antonio García Quintana, María del

Val Groba Marco 


\section{References}

1. Vázquez de Prada JA. Registro Nacional de Trasplante Cardiaco. Primer informe oficial. Rev Esp Cardiol., 44 (1991), pp. 293-296

2. Vázquez de Prada, JA, Arizón JM, Almenar Bonet L, González-Vílchez F. Registro Español de Trasplante Cardiaco. Una visión histórica. Rev Esp Cardiol Supl., 15 (2015), pp. 27-30

3. González-Vílchez F, Gómez-Bueno M, Almenar-Bonet L. Spanish Heart Transplant Registry, et al. 28th official report of the Spanish Society of Cardiology Working Group on Heart Failure (1984-2016). Rev Esp Cardiol., 70 (2017), pp. 1098-1109

4. González-Vílchez F, Almenar-Bonet L, Crespo-Leiro MG, et al. Spanish Heart Transplant Registry. 29th official report of the Spanish Society of Cardiology Working Group on Heart Failure. Rev Esp Cardiol., 71 (2018), pp. 952-960

5. González-Vílchez F, Almenar-Bonet L, Crespo-Leiro MG, et al. Spanish Heart Transplant Registry. 30th Official Report of the Spanish Society of Cardiology Working Group on Heart Failure (1984-2018). Rev Esp Cardiol., 72 (2019), pp. 954-962

6. Barge-Caballero E, González-Vílchez F, Delgado JF, et al. Use of intra-aortic balloon pump as a bridge to heart transplant in Spain: results from the ASIS-TC Study. Rev Esp Cardiol., 72 (2019), pp. 835-843

7. Barge-Caballero E, Almenar-Bonet L, González-Vílchez F, et al. Clinical outcomes of temporary mechanical circulatory support as a direct bridge to heart transplantation: a nationwide Spanish registry. Eur J Heart Fail., 20 (2018), pp. 178-186

8. Khush KK, Cherikh WS, Chambers DC, et al. The International Thoracic Organ Transplant Registry of the International Society for Heart and Lung Transplantation: Thirty-sixth adult heart transplantation report - 2019; focus theme: Donor and recipient size match. J Heart Lung Transplant., 38 (2019), pp. 1056-1066. 